UDC 81

DOI https://doi.org/10.32838/2710-4656/2021.4-2/13

Shukurlu Savad

orcid.org/0000-0002-5557-3362

Baku Slavic University

\title{
VERBALIZATION OF CONCEPT "MORALITY" IN THE MODERN AZERBAIJANI LANGUAGE
}

The article deals with the analysis of the means of verbalization of the concept "morality" in the Azerbaijani language. At both the conceptual and lexico-semantic levels, "morality" is associated with "behavior". The basic word representing this concept in the Azerbaijani language is the word axlaq. In the semantic structure of this word, as the basic nominative, the meaning "behaviour" is determined. However, most often in the consciousness of modern Azerbaijanis, this word is associated with morality and decency. Accordingly, the word axlaq is most often used in the sense of "morality" or "decency". In fact, in Azerbaijani language this term and the corresponding behavior are never perceived neutrally. The word axlaq is already comprehended by native speakers in any speaking situation as the signal of high morality and responsibilities for personal behavior but not as the designation of behavior at all. For comparison it can be stated that the examined definition in $D$. N. Ushakov's Dictionary - "a set of norms determining a person's behavior" - does not possess such a meaning. Consistency of lexico-semantical paradigms play a supreme role here, since the synonyms like antonyms split the concept into lexical components. This takes place through differential features which not only distinguish words in a synonymous line ensuring their value, but also submits a detailed insight into a concept. The case of the lexical paradigm examined by us enabled us to understand that morality for the Azerbaijani people is not least connected to decency in appearance. As for the most decent state in outer look, it includes not only clothing but also manners. Decency assumes even the specifics of gestures and movements. We can show an example of palm movement for closing mouth which is typical for women. According to decency rules, an Azerbaijani woman is not permitted to give a hand to a man or raise eyes while talking. In that way, even superficial methods of analysis on verbalization of the concept "morality" in the Azerbaijani language approve that it has in itself a frame-based nature and covers not only linguistic but also paralinguistic elements.

Key words: concept, morality, Azerbaijani language, domain, lexical meaning, lexical paradigm.

Introduction. In the modern linguistics of Azerbaijani language, a special importance is given to analysis, allowing to clarify the peculiarities of ethnomental overview of notions at a certain level. In the current article, the lexico-semantical groups that reflect the Azerbaijani people's idea of morality are in the center of our attention. Of course, the concept 'morality' is not verbalized only in these words. The conceptual content is introduced in the national phraseology, proverbs and sayings, oral folk arts and even in contemporary texts. But the corresponding lexico-semantical group, first of all, provides an insight into the boundaries of the conceptual field. A significative with a lexical meaning should not be compared to a concept, nevertheless the necessary domain can conceptually be designated.

Discussion. The main lexeme which defines "morality" in the Azerbaijani language is the word "oxlaq". This word originates from Arabic language. In the dictionary containing Arabic and Persian words that are used in Azerbaijani language, the word $x$ xlaq is not fixed, but the word "oxlaqi", a derivative adjective with the meaning of "peculiar behavior related with a person's character" is introduced [6, p. 200]. Our conception of behavior is certainly associated with conceptions of morality, but conceptually they are not the same things. For example, in the Dictionary of D. N. Ushakov, the term morality has three definitions. The first is defined as "a set of norms determining the behavior of people" [2, p. 120]. The second - "the very behavior of a person". The third is "moral characteristics" [2, p. 120]. The first and the third meanings, in our opinion, are difficult to differentiate, because if a person's behavior rests upon the norms, then this person is consequently moral one. But if it is not compatible with the norms, this state and behavior is defined with the same terms only by adding negative affixes: immoral, amoral. Typically, the second meaning, which is defined as "the very behavior of a person", that is beyond 
the valuation of qualities within the scale of morality, an illustration is developed just having a relation with behavior valuation: a person with high morality" [2, p. 120].

The semantic structure of the word axlaq in the Explanatory dictionary of Azerbaijani language is idenfied as follows: "OXLAQ 1. İnsanın mənəvi keyfiyyətini, əhvali-ruhiyyəsini müəyyən edən etik normalar, mənəviyyat. 2. İnsanın yaşadığ 1 cəmiyyət və onu təşkil edən üzvləri ilə rəftarı və özünü aparma qaydası" [4, p. 75]. The given statements can be translated into English as follows: "1. morality, set of ethic norms determining a person's moral quality and spirit (mood). 2. a person's attitude towards the society in which he lives in, and the members forming it, as well as his behavior". As seen, an idea of ethics immediately appears here, which is associated with high qualities and high morality in our perception. In fact, in Azerbaijani language this term and the corresponding behavior are never perceived neutrally. The word axlaq is already comprehended by native speakers in any speaking situation as the signal of high morality and responsibilities for personal behavior but not as the designation of behavior at all. For comparison it can be stated that the examined definition in D. N. Ushakov's Dictionary - "a set of norms determining a person's behavior" - does not possess such a meaning.

For example, the norms can be anyhow and not always are characterized by high morality.

In the new "Dictionary of Synonyms of Azerbaijani language", the words like 'ayağısürüsskn, etika, manəviyyat, torbiyə' are introduced at the entry for axlaq [5, p. 118]. The lexemes etika, manəviyyat and tarbiya do not provoke objections. The first one is an equivalent to the Russian term этика (ethics) and has a direct meaning of 'norms of behavior'. The second one means "morality", "spirituality". And the third - "upbringing". As for the first word in this line, it does not match with its integral characteristics at all. The dictionary does not explain the meaning of the word ayağısürüskan, though, by etika it is stated in parenthesis that these are moral norms, by manəviyyat - high morality, by torbiyz - excellent morality (gözal axlaq). The term ayăgısürüşkən in Azerbaijani language means "a woman with low morality", "streetwalker", "a woman who can easily cheat her husband". In the four-volume azerbaijani-russian dictionary, the entry for this term has an extremely expressive character: "AYAĞISÜRÜŞKӘN spok. 1. Adj. lustful, dissolute, lecherous (a woman with low morality); 2. n. rake, libertine" [3, p. 85].
For us, the clarification note in parenthesis is absolutely unnecessary. Only a woman can be lustful, dissolute and lecherous, herewith telling "a woman with a lower behavior" will reduce expressiveness. Nevertheless, it seems there is a difference between the notions 'lustful' or 'dissolute' and "a woman with poor behavior'. The Azerbaijani people typically relate 'ayağısürüşkən' to a woman who can easily fall in love and is amative, but not necessarily lustful. In MAC, (Малый академический словарь) the definition of the term lustful is defined as "full of lust", and lust as "sexual appetite or desire" [1, p. 341]. The words lust and lustful designate really very strong feelings and hardly match with the notion of "a woman with low behavior".

Our mission does not include the analysis of lexical entries from Azerbaijani-Russian dictionaries. It is absolutely strange how this term was presented at the entry for the word axlaq. It cannot be a result of simple inattention. As for logics, it is difficult to catch it here. The point is that the term ayağısürüşkən has an opposite meaning that is "immorality".

The words manəviyyat and tarbiya attract attention in the Dictionary of Synonyms. As stated before, the first one is defined as "high morality" and the last as "excellent morality". In fact, the Azerbaijani word tarbiyz in its basic nominative meaning has the definition of nothing else but "воспитание" (upbringing). It seems that the compilers of the dictionary meant "excellent behavior" as a synonym to the concept "morality", not vice versa, i.e. not "upbringing" as "excellent morality". As for the word "manaviyyat", it is used, as a rule, in the meaning of "spirituality" or "morality".

In the Azerbaijani language, the conception of "morality" is not realized only in the context where one of the following words is present: axlaq, manaviyyat, tarbiya. The conception of morality, for instance, is widely introduced in the Azerbaijani phraseology. For example, in the system of notions on the Azerbaijani moralities, mental phenomena occupy a large space, which are designated through the lexeme abir. Regarding the usage frequency, not any synonymous word is able to compete with the term abir and paradigms formed through it. The heaviest insult for the Azerbaijani people is considered to be the expression abirsiz, that is 'a person lacking the feeling associated with abır'. In the Azerbaijanirussian dictionary, the basic nominative meaning of this word is defined as "appearance, outer look. The second is - as "shame", and third is - "disgrace" [3, p. 35]. To our viewpoint, in the contemporary Azerbaijani language, the main definition of this 
word is "decency". Exactly this meaning is found out in the structure of the most widespread fixed word combinations and phraseological units. Besides, the word abir itself is mostly used in the sense of "decency". The definition of "shame" is not commonly associated with the word abir, but rather with its derivative abirsiz - shameless.

In the Azerbaijani-Russian phraseological dictionary by A. A. Orujov, a whole series of phraseologisms, combined with the word abir, is identified. In this minor dictionary, there are 25 phraseological units in combination with this term [7, p. 33-34]. The analysis of these expressions allows us to imagine which place the conception of "decency" occupies in the viewpoint of the Azerbaijani nation. In general, the rules of decency were and are given great importance to in the Islamic, as much as Caucasian value system. If, for example, we try to draw the frames of "decency", it seems, we will also have to speak about the appearance of people, both men and women. Conceptions of walking, table manners, speaking, laughing and etc. have also relations to it. For instance, Muslim and Caucasian gravity, proud bearing, slow walking, silent and measured speech are depicted in fiction and cinematography not seldom even in a comical way. An outer look is exactly what is chiefly associated with morality of a person. Apparently, that is the reason why the first definition of the term abir is identified as "appearance, outer look". However, there is a moment which is important to pay attention to. So, the word abir in the sense of "appearance" is primarily associated with the loss of decency in clothing and outer look. The conception of "indecency" forms, as if, a presupposition of the word abir in the sense of "outer look". The word abır, as a rule, in this meaning is, therefore, encountered in the expressions bu abir or bu abirda which express blame, reproach, the interpretation of which is "what kind of an appearance is it?". Furthermore, the concept "decency" bears more general meaning in comparison with the concept "decency in outer look" or metonymy just "outer look". All the stated arguments give grounds to consider that the basic nominative meaning of the Azerbaijani word abır is exactly "decency". We can even suppose that idea of "decency" and the notion "decency" occupies an important place in the structure of the conception "morality". In this connection there is a confusion about the fact that the word abir is not introduced at the entry regarding the lexeme axlaq in the synonyms dictionary. Thus available dictionaries do not always provide a holistic view about the character of verbalization of the concept "morality" in Azerbaijani language. Of course, any concept is verbalized not only by means of lexical units. Phraseological and paremiological units, as well as, folklore texts are playing a big part in revealing conceptual content. However, the system of lexicogrammatical units having a direct association with one or another concept which occupies an important place in the nation's viewpoint, first of all, is represented on the level of detail.

Conclusions. Consistency of lexico-semantical paradigms play a supreme role here, since the synonyms like antonyms split the concept into lexical components. This takes place through differential features which not only distinguish words in a synonymous line ensuring their value, but also submits a detailed insight into a concept. The case of the lexical paradigm examined by us enabled us to understand that morality for the Azerbaijani people is not least connected to decency in appearance. As for the most decent state in outer look, it includes not only clothing but also manners. Decency assumes even the specifics of gestures and movements. We can show an example of palm movement for closing mouth which is typical for women. According to decency rules, an Azerbaijani woman is not permitted to give a hand to a man or raise eyes while talking. In that way, even superficial methods of analysis on verbalization of the concept "morality" in the Azerbaijani language approve that it has in itself a frame-based nature and covers not only linguistic but also paralinguistic elements. In other words, the culture-historical nature of the concepts about morality is reflected in the language. Since the concept "morality" bears a comprehensive character and covers factually all spheres of popular life, it would be naïve to expect its thorough and detailed study in separate researches. Nevertheless, separate researches, in a systematic and integrated way, can totally study the conceptual content of "morality" in semantic spheres that analyze the basic lexemes from the point of view of paradigmatics and syntagmatics.

\section{References:}

1. 4-volume Dictionary of Russian Language AH USSR. Volume 3. M. : Russian language, 1984.

2. Ushakov D. N. Explanatory dictionary of Russian language. Volume 2. M. : World of Books, 2001.

3. Azerbaijani-Russian dictionary in 4 volumes. $1^{\text {st }}$ volume. Baku : Science, 1986.

4. Explanatory dictionary of Azerbaijani language. 4 volumes. II volume. Baku : East-West, 2006. 
5. Dictionary of Synonyms of Azerbaijani Language. Baku : East-West, 2012.

6. Dictionary of Arabic and Persian Words. Baku : Publishing House under the Academy of Sciences of Azerbaijan USSR, 1966.

7. Orujov A. A. Phraseological Dictionary of Azerbaijan-Russian Languages. Baku : Science, 1976.

\section{ШУкурлУ Савад. ВЕРБАЛІЗАЦІЯ ПОНЯТТЯ «МОРАЛЬ» У СУЧАСНІЙ АЗЕРБАЙДЖАНСЬКІЙ МОВІ}

Стаття присвячена аналізу засобів вербалізачії поняття «мораль» в азербайджанській мові. I на концептуальному, і на лексико-семантичному рівнях «мораль» асочіюється з «поведінкою». Основним словом, щзо представляє це поняття в азербайджанській мові, є слово дхlаq. У семантичній структурі иъого слова як основного номінативу визначається значення «поведінка». Однак найчастіше у свідомості сучасних азербайджанців ие слово асоиіюється з мораллю й порядністю. Відповідно, слово oxlaq найчастіше вжсиваться в значенні «мораль» або «порядність». Насправді в азербайджанській мові ией термін і відповідна поведінка ніколи не сприймаються нейтрально. Слово әхая уже сприймається носіями мови в будь-якій мовленнєвій ситуації як сигнал високої моральності та відповідальності за особисту поведінку, але не як позначення поведінки загалом. Для порівняння можна сказати, щзо розглянуте визначення в Словнику Д. Н. Ушакова - «сукупність норм, щзо визначають поведінку людини», - не має такого значення. Послідовність лексико-семантичних парадигм відіграє тут найвищу роль, оскільки такі синоніми, як й антоніми, розбивають поняття на лексичні компоненти. Це відбувається завдяки різним ознакам, які не лише розрізняють слова в синонімічному рядку, забезпечуючи їх значення, а й надають детальне розуміння поняття. Випадок розглянутої нами лексичної парадигми дав нам змогу зрозуміти, що мораль азербайджанського народу не в останню чергу пов'язана з порядністю в зовнішності. Що стосується найбільш пристойного зовнішнього вигляду, він включає не тільки одяг, а й манери. Порядність передбачає навіть специфіку жестів і рухів. Ми можемо показати приклад руху долоні для закриття рота, щңо характерно для жінок. Згідно з правилами пристойності, азербайджаниі не дозволяється подавати руку чоловікові або піднімати очі під час розмови. Таким чином, навіть поверхові методи аналізу вербалізачї поняття «мораль» в азербайджанській мові підтверджують, щзо воно має кадровий характер та охоплює не лише лінгвістичні, а й паралінгвістичні елементи.

Ключові слова: поняття, мораль, азербайджанська мова, предметна галузь, лексичне значення, лексична парадигма. 